\title{
PENERAPAN LKS EKSPERIMEN PADA KONSEP ASAM DAN BASA TERHADAP HASIL BELAJAR SISWA SMP NEGERI 1 MASOHI KABUPATEN MALUKU TENGAH
}

\author{
Sofia Latumahina ${ }^{1}$, Semuel Unwakoly ${ }^{\star 2}$ \\ ${ }^{1}$ Sekolah Menengah Pertama Negeri 1 Nusalaut, Kabupaten Maluku Tengah \\ ${ }^{2}$ Program Studi Pendidikan Kimia, Jurusan Pendidikan MIPA FKIP Unpatti \\ *semuel.unwakoly@fkip.unpatti.ac.id
}

\begin{abstract}
ABSTRAK
Proses pembelajaran yang kurang menarik dengan hanya berorientasi pada guru dan tidak mengembangkan kemampuan berpikir siswa serta sarana pendukung yang tidak memadai di kelas, merupakan penyebab hasil belajar siswa SMP Negeri 1 Masohi pada materi Kimia tidak mamuaskan. Untuk dapat memperbaiki hasil belajar maka diperlukan penerapan media yang sesuai dengan kebutuhan proses pembelajaran. Salah satu media yang dapat digunakan dalam proses pembelajaran kimia adalah dengan menerapkan eksperimen atau demonstrasi di kelas. Sehubungan dengan hal tersebut di atas, maka penerapan Lembar Kerja Siswa (LKS) Eksperimen sebagai media pembelajaran dianggap sebagai salah satu cara yang tepat untuk dapat meningkatkan hasil belajar siswa. Penelitian ini dilakukan untuk mengetahui penerapan LKS Eksperimen pada konsep asam dan basa terhadap hasil belajar siswa kelas VII SMP Negeri 1 Masohi Kabupaten Maluku Tengah. Penelitian bersifat deskriptif kuantitatif yang merupakan metode yang tepat untuk melihat hasil belajar yang akan diperoleh. Data penelitian yang diperoleh adalah sebanyak 32 siswa $(100 \%)$ mencapai ketuntasan belajar dengan 14 siswa $(43,8 \%)$ dengan kualifikasi sangat baik, dan 18 siswa $(56,2 \%)$ dengan kualifikasi baik pada konsep asam dan basa. Hal ini menunjukkan bahwa dengan melakukan eksperimen dengan menggunakan LKS dapat membantu penguasaan konsep belajar dari siswa pada materi-materi kimia di SMP.
\end{abstract}

Kata Kunci: LKS eksperimen, asam dan basa, hasil belajar.

\section{PENDAHULUAN}

Salah satu masalah yang dihadapi pendidikan saat ini adalah masalah lemahnya proses pembelajaran. Dalam proses pembelajaran, siswa kurang didorong untuk mengembangkan kemampuan berpikir, sehingga proses pembelajaran di dalam kelas hanya diarahkan pada kemampuan siswa untuk menghafal informasi, otak siswa dipaksa untuk mengingat dan menimbun berbagai informasi yang diingatnya untuk menghubungkannya dengan kehidupan sehari-hari. Akibatnya, ketika siswa lulus dari sekolah mereka pintar secara teoritis tetapi miskin aplikasinya (Sanjaya : 2006).

Sesuai dengan Kurikulum Tingkat Satuan Pendidikan (KTSP) di Indonesia yang termuat dalan Peraturan Pemerintah Nomor 19 Tahun 2005 tentang Standar Nasional Pendidikan, bahwasanya diharapkan siswa bukan lagi sebagai objek pembelajaran tetapi sebagai subjek pembelajaran, sehingga keberadaan eksperimen atau praktikum sebagai metode pembelajaran kimia merupakan suatu keharusan. Melalui eksperimen siswa belajar menemukan konsep sendiri atau bersamasama dengan teman-teman sekerjanya dalam kelompok, sekaligus membantu pemahaman konsep yang diajarkan di kelas.

Kimia merupakan salah satu ilmu pengetahuan yang mempunyai peranan penting dalam berbagai bidang kehidupan. Dengan demikian perlu adanya suatu gagasan atau pola pikir yang berguna untuk mengembangkan ilmu kimia ke depan agar lebih baik melalui penerapan metode yang tepat, salah satunya dengan melakukan eksperimen. Artinya bahwa tidak mungkin belajar kimia tanpa laboratorium dengan memanfaatkan bahan-bahan kimia disekitar kita. 
Ciri dari ilmu kimia adalah ilmu yang berlandaskan praktik dan eksperimen. Para siswa yang mempelajari ilmu kimia, tidak hanya merasa mengerti pada setiap ilmu pengetahuan yang didapatkan secara kognitif, tetapi siswa tersebut harus mempraktekannya, menyelesaikan soal-soal berdasarkan materi yang telah dijelaskan atau pun melakukan suatu ketrampilan ilmiah. Dengan demikian, melalui pembelajaran kimia, siswa diharapkan terlatih berpikir secara sistematis dan ilmiah. Hal ini disebabkan karena ilmu kimia sangat erat dengan hubungan sebab akibat sehingga siswa dapat memahami fakta atau gejala alam secara rasional.

Kekurangan atau tidak tersedianya berbagai bahan dan alat kimia seringkali menjadi kendala tidak berlangsungnya suatu topik eksperimen. Menghadapi kendala seperti ini sudah saatnya dunia pendidikan terutama yang terkait dalam proses pembelajaran yaitu guru dan siswa untuk memikirkan jalan keluarnya seperti diketahui "dunia kita adalah dunia kimia". Artinya segala yang ada di dunia ini tidak terlepas dari aspek kimiawi. Hal ini memberikan inspirasi bahwa lingkungan sekitar sebenarnya merupakan sarana belajar kimia untuk menunjukan fenomena-fenomena kimiawi seperti yang tertulis dalam pelajaran kimia yang diajarkan di kelas (Filindity, 2008).

Lembar Kerja Siswa (LKS) dapat dianggap sebagai atau suatu media atau alat pembelajaran, karena digunakan oleh guru sebagai perantara dalam melaksanakan kegiatan pengajaran untuk mencapai tujuan intruksional khusus atau tujuan pembelajaran khusus. Pengertian LKS yang dikemukakan oleh Bulu yaitu " LKS ialah lembar kerja yang berisi informasi perintah/instruksi dari guru kepada siswa untuk mengerjakan suatu kegiatan belajar dalam bentuk kerja, praktek, atau dalam bentuk penerapan hasil belajar untuk mencapai satu tujuan."

Materi asam dan basa merupakan salah satu materi kimia pada jenjang SMP yang ada hubungannya dengan peristiwa- peristiwa di sekitar kita. Dengan melakukan eksperimen siswa lebih memahami konsep asam dan basa, tidak hanya secara teori saja tetapi bisa mengamati sendiri peristiwa-peristiwa tersebut.

Proses pembelajaran kimia di SMP Negeri 1 Masohi, Kabupaten Maluku Tengah selama ini hanya mengacu pada buku paket dan berpusat pada guru (teacher centre). Penggunaan bahan ajar dinilai kurang menarik untuk membantu siswa dalam proses pembelajaran, hal ini berdampak pada hasil belajar yang kurang memuaskan dari setiap siswa pada tahun-tahun ajaran sebelumnya. Selain itu, laboratorium kimia yang merupakan sarana yang sangat penting dalam pembelajaran kimia tidak tersedia, sehingga mata pelajaran kimia yang diajarkan oleh guru hanya secara teori saja. Berdasarkan uraian diatas, perlu dilakukan penelitan dengan menerapkan media LKS eksperimen dengan tujuan untuk dapat membantu siswa dalam memahami konsep asam basa serta mengetahui hasil belajar siswa pada kelas VII SMP.

\section{METODE PENELITIAN}

Metode yang digunakan dalam penelitian ini adalah kuantitatif dengan tipe deskriptif, yakni menggambarkan penerapan eksperimen sains dalam meningkatkan hasil belajar siswa, dengan model one group pre-test post-test design dari Truchaman.

Populasi dalam penelitian ini adalah seluruh siswa kelas VII SMP Negeri 1 Masohi Kabupaten Maluku Tengah, sedangkan sampel yang digunakan adalah siswa kelas VII.5 yang berjumlah 32 orang. Instrumen penelitian yang digunakan berupa instrumen tes, post test dalam bentuk pilihan ganda untuk mengukur kemampuan kognitif siswa, instrumen non-test, berupa lembaran pengamatan yang berupa lembar pengamatan sikap, dan psikomotor, serta lembar kerja siswa (LKS).

Teknik analisa data yang digunakan untuk menganalisa data dalam penelitian ini adalah dengan menganalisis secara deskriptif kuantitatif.

$$
\text { Nilai }=\frac{\text { imlah shor yang diperolsh }}{\text { fusniah shor total }} \times 100
$$

Sedangkan nilai akhir (NA) diperoleh dengan menggunakan rumus : 
$\mathrm{NA}=\frac{75(x 2)+25(X 1)}{10 \mathrm{n}}$

Keterangan :

$X_{1}=$ Penilaian formatif

$\mathrm{X}_{2}=$ Penilaian proses (kognitif, afektif dan psikomotor) dengan Kontribusi untuk aspek kognitif $30 \%$, aspek afektif $20 \%$ dan aspek psikomotor $50 \%$.

Tabel 1. Konversi nilai KKM SMP Negeri 1 Masohi Tahun Ajaran 2011/2012

\begin{tabular}{ccc}
\hline $\begin{array}{c}\text { Tingkat Penguasaan } \\
\text { Kompetensi }\end{array}$ & $\begin{array}{c}\text { Nilai } \\
\text { Huruf }\end{array}$ & Kualifikasi \\
\hline $81-100$ & A & Sangat baik \\
$61-80$ & B & Baik \\
$41-60$ & C & Cukup \\
$<40$ & D & Kurang \\
\hline
\end{tabular}

Data pengamatan pada penelitian ini adalah data observasi kegiatan siswa selama proses belajar-mengajar berlangsung. Kemudian mengkonversikan nilai akhir yang berbentuk ukuran kuantitatif ke dalam bentuk komentar tuntas atau tidak sesuai dengan standar ketuntasan minimal (SKM) Kimia SMP Negeri 1 Masohi.

Tabel 2. Tingkat Penguasaan Kompetensi dan Kualifikasi

\begin{tabular}{cl}
\hline $\begin{array}{c}\text { Tingkat Penguasaan } \\
\text { Kompetensi }\end{array}$ & \multicolumn{1}{c}{ Kualifikasi } \\
\hline $81-100$ & Sangat Baik \\
$61-80$ & Baik \\
$41-60$ & Kurang \\
$20-40$ & Sangat Kurang \\
$<20$ & Gagal \\
\hline
\end{tabular}

\section{HASIL PENELITIAN}

Hasil penelitian yang dicapai disajikan deskripsi tingkat penguasaan siswa kelas VII SMP Negeri 1 Masohi pada materi asam dan basa adalah sebagai berikut :

a. Hasil belajar siswa yang dimulai proses pembelajaran dengan menggunakan LKS.

\section{Kemampuan kognitif siswa}

Data kemampuan kognitif siswa selama proses pembelajaran dapat dilihat melalui lembaran kerja siswa (LKS) pada lampiran 10 sedangkan data dan kualifikasi hasil belajar siswa dengan tingkat penguasaan LKS digambarkan pada tabel 3 di bawah ini:

Tabel 3. Data kualifikasi rata-rata presentase (\%) pencapaian LKS

\begin{tabular}{cccl}
\hline & \multicolumn{2}{l}{ Kelas VIII } & Kualifikasi \\
\cline { 1 - 3 } Nilai & Frek & $\begin{array}{c}\text { Frekuensi } \\
\text { Relatif }(\%)\end{array}$ & \\
\hline $86-100$ & 8 & 25 & Sangat \\
& & & Baik \\
$75-85$ & 22 & 69 & Baik \\
$65-74$ & 2 & 6 & Cukup \\
$<65$ & 0 & 0 & Kurang \\
\hline
\end{tabular}


Tabel 3 di atas menggambarkan bahwa semua siswa mampu menguasai indikator-indikator pembelajaran. Terlihat bahwa penguasaan siswa terhadap materi asam dan basa dengan kualifikasi sangat baik berjumlah $25 \%$, tingkat penguasaan baik berjumlah $69 \%$, tingkat penguasaan dengan kualifikasi cukup 6\%.

Keberhasilan siswa pada aspek kognitif dengan kualifikasi sangat baik diperoleh dari penguasaan materi dan kemampuan siswa menjawab soal-soal tes, dengan tingkat kesukaran yang mudah, dan dengan kualifikasi sangat baik dan baik, sedangkan keberhasilan siswa dengan kualifikasi cukup diperoleh dari kemampuan siswa menjawab soal-soal tes dengan tingkat kesukaran yang tinggi. Hal ini dapat dilihat pada proses presentase pencapain proses melalui LKS selama proses pembelajaran Tabel 3.

Sejalan dengan itu Slavin (1995) berpendapat bahwa siswa akan lebih mudah menemukan dan memahami konsep yang sulit apabila mereka saling mendiskusikan konsep itu dengan temantemannya. Siswa juga akan bekerjasama dalam belajar dan ber-tanggungjawab terhadap pembelajaran teman sekelasnya serta ber-tanggungjawab atas pembelajarannya sendiri. Dalam kelompok dengan kemampuan yang heterogen siswa belajar bersama dalam kelompok kecil yang membantu satu sama lain serta melatih siswa menerima perbedaan pendapat dalam bekerja dengan teman yang berbeda latar belakangnya. Selama bekerja dalam kelompok, tugas anggota kelompok adalah mencapai ketuntasan (Wenno, 2008:57-58).

\section{Kemampuan afektif Siswa}

Hasil belajar siswa pada apek afektif dengan kualifikasi presentase tingkat penguasaan digambarkan pada tabel 4 .

Tabel 4. Kualifikasi rata-rata presentase (\%) pencapaian aspek afektif

\begin{tabular}{cccc}
\hline Nilai & \multicolumn{2}{c}{ Pertemuan I } & Kualifikasi \\
\cline { 2 - 3 } & Frek & $\begin{array}{c}\text { Frekuensi } \\
\text { relatif }(\%)\end{array}$ & \\
\hline $81-100$ & 12 & 37,5 & Sangat Baik \\
$61-80$ & 20 & 62,5 & Baik \\
$41-60$ & 0 & 0,0 & Cukup \\
$<40$ & 0 & 0,0 & Kurang \\
\hline
\end{tabular}

Pada tabel 4 menunjukan bahwa sikap yang dinilai melalui lembaran penelitian dengan kualifikasi sangat baik $37,5 \%$, mampu bersikap baik pada semua aspek yang dinilai dengan kualifikasi baik $62,5 \%$ dan tidak terdapat siswa dengan tingkat peguasaan cukup, maupun gagal.

Aspek afektif dalam penelitian memperlihatkan sikap memperhatikan, keseriusan, kesopanan dan ketertiban siswa dalam proses pembelajaran yang terkait dengan materi asam dan basa. Hasil penelitian menunjukkan bahwa sebagian besar siswa memperhatikan materi yang disampaikan guru, siswa yang sangat serius dan bertanggungjawab mengerjakan LKS dalam kelompoknya masing-masing, siswa sangat sopan dalam menjawab pertanyaan yang diajukan guru maupun teman mereka, serta menjaga ketertiban dalam kelas selama proses pembelajaran.

\section{Kemampuan psikomotor siswa}

Kemampuan pisikomotor siswa yang dimulai selama proses pembelajaran dapat ditunjukan pada tabel 5 . 
Tabel 5. Kemampuan psikomotor

\begin{tabular}{cccc}
\hline Nilai & \multicolumn{2}{c}{ Pertemuan I } & Kualifikasi \\
\cline { 2 - 3 } & Frek & $\begin{array}{c}\text { Frekuensi } \\
\text { relatif }(\%)\end{array}$ & \\
\hline $81-100$ & 21 & 65,6 & Sangat baik \\
$61-80$ & 11 & 34,4 & Baik \\
$41-60$ & 0 & 0,0 & Cukup \\
$<40$ & 0 & 0,0 & Kurang \\
\hline
\end{tabular}

Pada tabel 5 menunjukan penilaian kerja siswa, sebanyak 65,6\% mampu bersikap baik pada semua aspek yang dinilai dengan kualifikasi sangat baik, 34,4\% dengan kualifikasi baik dan tidak terdapat siswa dengan penguasaan cukup maupun gagal. Aspek psikomotor menunjukkan bahwa sebagian besar siswa memperhatikan materi dan mengerjakan LKS dalam kelompoknya masingmasing dengan baik dan serius, serta siswa mampu menguasai materi dalam LKS serta mampu menggunakan alat-alat dan bahan-bahan dengan baik. Siswa yang terbiasa menggunakan alatalat laboratorium, maka siswa tersebut akan lebih mudah bereksperimen dengan menggunakan alat-alat tersebut. Hasil belajar psikomotor ini sebenarnya menunjukan kelanjutan dari hasil belajar kogntif (memahami sesuatu) dan hasil belajar afektif (yang baru tampak dalam bentuk kecenderungan dan berperilaku). Hasil belajar kognitif dan hasil belajar afektif akan mendukung hasil belajar psikomotor apabila siswa telah menunjukan perilaku atau perubahan tertentu dengan makna yang terkandung dalam ranah kognitif dan ranah afektifnya (Sudjiono, 1995:57).

\section{Deskripsi tingkat penguasaan siswa hasil tes formatif}

Tes formatif diberikan pada akhir proses pembelajaran materi asam dan basa. Data kualifikasi tingkat penguasaan siswa pada tes formatif dapat ditunjukan pada tabel 6 .

Tabel 6. Kualifikasi tingkat penguasaan hasil tes formatif

\begin{tabular}{cccc}
\hline Nilai & Frek. & $\begin{array}{c}\text { Frek. relatif } \\
(\%)\end{array}$ & Kualifikasi \\
\hline $81-100$ & 7 & 21,9 & Sangat baik \\
$61-80$ & 17 & 53,1 & Baik \\
$41-60$ & 8 & 25,0 & Cukup \\
$<40$ & 0 & 0,0 & Kurang \\
\hline
\end{tabular}

Tabel 6 menunjukkan bahwa tingkat penguasaan siswa terhadap hasil tes formatif dengan kualifikasi sangat baik berjumlah $21,9 \%$, kualifikasi baik $53,1 \%$ dan kualifikasi cukup berjumlah $25,0 \%$. Hal ini menunjukan bahwa siswa yang menguasai indikator pembelajaran sebanyak 32 siswa (100\%), dan mampu mencapai kriteria ketuntasan minimal (KKM) dan tidak ada siswa yang belum/gagal menguasai indikator pembelajaran. Hal ini merupakan salah satu bentuk proses pembelajaran sains yang menghadirkan siswa untuk melakukan tindakan (action) nyata dalam kehidupan sehari-hari artinya pembelajaran yang diajarkan itu benar-benar membantu siswa untuk mengembangkan kemampuan konstruktivisnya (action knowledge) (Wenno, 2008:25-26).

\section{KESIMPULAN}

1. Hasil penilaian aspek kognitif menunjukan bahwa semua siswa mampu menguasai indikator pembelajaran dengan kualifikasi sangat baik, baik dan cukup. Kualifikasi sangat baik berjumlah 8 siswa (25\%), tingkat penguasaan baik berjumlah 22 siswa (69\%), tingkat penguasaan dengan kualifikasi cukup 2 siswa (6\%). 
2. Aspek afektif yang diperoleh siswa terhadap tingkat penguasaan dengan kualifikasi sangat baik berjumlah 12 siswa, tingkat penguasaan dengan kualifikasi baik berjumlah 20 siswa, sedangkan tingkat penguasaan siswa dengan kualifikasi cukup dan gagal tidak ada.

3. Tingkat penguasaan siswa pada aspek psikomotor dengan kualifikasi sangat baik berjumlah 21 siswa, sedangkan tingkat penguasaan siswa dengan kualifikasi baik berjumlah 11 siswa dan tidak terdapat siswa dengan kualifikasi cukup dan kurang.

4. Hasil yang diperoleh siswa dari tes formatif menunjukan bahwa siswa yang menguasai indikator pembelajaran sebanyak 32 siswa $(100 \%)$, hal ini menunjukan bahwa semua siswa mampu mencapai kriteria ketuntasan minimal (KKM) dan tidak ada siswa yang belum/gagal menguasai indikator pembelajaran.

\section{DAFTAR PUSTAKA}

Filindity, Y. 2008. Praktikum Sains Kimia Berbasis Lingkungan, Jurnal IImiah Pendidikan, ILPEN, Volume 1. Ambon: APMK Maluku

Sanjaya, W. 2006. Strategi Pembelajaran Berorientasi Standar Proses Pendidikan. Jakarta: Kencana Prenada Media Group

Slavin, Robert E, 1995. Cooperative Learning. Nusa Media, Jakarta

Sudijono, 1995. Pengantar Evaluasi Pendidikan. Yogyakarta: Grafindo Persada

Wenno, I, H. 2008. Strategi Belajar Mengajar Sains Berbasis Kontekstual. Penerbit Inti Media, Yogyakarta 